\title{
Potential of Red Okra Extract (Abelmoschus esculentus L. Moench) to Restore Kidney Damage due to Sodium Nitrite
}

\author{
Sri Puji Astuti Wahyuningsih ${ }^{1}$, Amalia Fachrisa ${ }^{1}$, Nabilatun Nisa, ${ }^{1}$, Baskara Wiku Adi \\ Kusuma $^{2}$, Nadia Shoukat ${ }^{1}$, Rasyidah Fauzia Ahmar ${ }^{1}$, Brigita Klara Krisdina Mamuaya ${ }^{1}$, \\ Na'ilah Insani Alifiyah',
}

\author{
${ }^{1}$ Department of Biology, Faculty of Science and Technology, Universitas Airlangga, Indonesia. \\ ${ }^{2}$ Faculty of Medicine, Universitas Airlangga, Surabaya Indonesia \\ *Corresponding Author: sri-p-a-w@fst.unair.ac.id
}

Submitted: 2020-12-30. Revised: 2021-02-07. Accepted: 2021-03-12

\begin{abstract}
Sodium nitrite $\left(\mathrm{NaNO}_{2}\right)$ found in vegetables, drinking water, and cured meats, can damage tissue because it is an oxidant. Plant phytochemicals such as quercetin are antioxidants. This study aimed to determine the potential of red okra pods ethanol extract (ROE) to repair kidney damage in mice (Mus musculus) induced by $\mathrm{NaNO}_{2}$. The red okra pods were extracted three times with saturated ethanol. The experiment used 36 male BALB/c mice aged 6-8 weeks and body weight of about 28 g. There are six research groups, namely, normal control, negative control (exposure to $\mathrm{NaNO}_{2} 50 \mathrm{mg} / \mathrm{kg} \mathrm{BW}$ ), treatment of exposure to $\mathrm{NaNO}_{2}$ and administration of $\mathrm{ROE}$ at doses of $25,50,75$, and $100 \mathrm{mg} / \mathrm{kg} \mathrm{BW}$. Sodium nitrite and ROE were given daily for 23 days by gavage. On day 24 , the serum was isolated. Blood urea nitrogen (BUN) and creatinine (Cre) levels are measured to assess kidney function, as well as measuring the oxidant malondialdehyde (MDA) and the antioxidant enzyme of superoxide dismutase (SOD). The kidneys were made histological preparations and analyzed on the proximal convoluted tubule (PCT). All data were statistically analyzed $(\alpha=0.05)$. This study indicated that the administration of ROE at a $100 \mathrm{mg} / \mathrm{kg} \mathrm{BW}$ dose is the most optimal in repairing damage to the PCT with increased normal cells and reduced necrosis. Besides, it degraded BUN, Cre, and MDA levels in the serum of mice exposed to $\mathrm{NaNO}_{2}$ compared to the other treatments. All doses of ROE promoted the SOD level. ROE restore kidney tissue, especially on PCT to normal. Kidney damage due to exposure to $\mathrm{NaNO}_{2}$ preservatives can be reduced by administering ROE. ROE prevents kidney damage through an increase in antioxidant enzymes. ROE can be used as a food ingredient as a source of antioxidants, thereby reducing the impact of oxidant compounds.
\end{abstract}

Key words: repair kidney damage; proximal convoluted tubule; red okra as antioxidant, sodium nitrite

How to Cite: Wahyuningsih, S. P. A., Fachrisa, A., Kusuma, B. W. A., Shoukat, N., Ahmar, R. F., Mamuaya, B. K. K., \& Alifiyah, N. I. (2021). Potential of Red Okra Extract (Abelmoschus esculentus L. Moench) to Restore Kidney Damage due to Sodium Nitrite. Biosaintifika: Journal of Biology \& Biology Education, 13(1), 84-91.

DOI: http://dx.doi.org/10.15294/biosaintifika.v13i1.28141

\section{INTRODUCTION}

The use of chemicals as additives in food is now easy to find in processed food and beverages. Sodium nitrite is a synthetic preservative that is widely used in the processed food industry, especially to make meat durable and not spoil quickly (Nur \& Suryani, 2011). Sodium nitrite $\left(\mathrm{NaNO}_{2}\right)$ is often used for preservative meat as a processed food product. Nitrite plays a major role in inhibiting the growth of foodborne pathogens Listeria monocytogenes, Clostridium perfringens, Achromobacter, Aerobacter, Escherichia, Flavobacterium, and Micrococcus spp Nitrite can inhibit the growth of pathogens and bacteria through various mechanisms, namely interference on oxygen uptake and oxidative phosphorylation, formation of nitrous acid and NOs, and interruption of critical enzymes in bacterial metabolism such as aldolase (Lee et al., 2018).

Besides, sodium nitrite can also increase the red color's quality in meat, so it has an attractive appearance (Wójciak et al, 2019). However, the continuous use of sodium nitrite can result in physiological changes. Sodium nitrite can be toxic and act as free radicals that increase oxidative stress (Baek et al., 2015). These can turn into nitrates and nitric oxide (NO). Changes occur due reduction and oxidation reactions (Ansari et al., 2017). These reactions generated reactive oxygen species (ROS) and reactive nitrogen species (RNS) which cause cytotoxicity and tissue damage. NO can bind with superoxide to form peroxynitrite (ONOO-). Peroxynitrite can react with polyunsaturated fatty acid (PUFA). It rapidly enhances lipid peroxidation and produce malondialdehyde (MDA). It damage the cell membrane and further causes tissue and organ deterioration

The kidneys are an excretory organ that plays an essential role in removing the remains of the body's metabolism, including toxic substances that are accidentally entered into the body. Consequently, kidneys become one of the organs that are readily induced by toxic substances like sodium nitrite. The toxic material is then reabsorbed in the proximal 
tubule. Parts of toxic substances are excreted via urine, and some will be left behind, which accumulate in the kidneys. The renal cortex is an area in the kidney that is sensitive to hypoxic states so that cell damage can occur in the form of swelling or even necrosis at the kidney scene (Kumar et al., 2015). Blood urea nitrogen (BUN) is the amount of urea concentration in serum or plasma. It is independently associated with chronic kidney disease development.

However, BUN level is related to kidney disfunction with moderate to severe (Seki et al., 2019). BUN levels can be used as an indicator of the glomerular filtration rate that illustrates the balance between urea production and excretion. Urea is produced from ammonia in the liver and is the end product of protein metabolism. The kidneys filter urea in the glomerular part, then the filtration product enters the Bowman's capsule, goes into the tubule, and is then secreted (Bijanti, 2010). Meanwhile, creatinine (Cre) is the result of creatine metabolism in muscle so that the amount of creatinine describes the body's muscle mass and stability in healthy individuals (Post et al., 2019).

Okra or Lady's Finger (Abelmoschus esculentus L. Moench) can be eaten raw or cooked. Various parts of the red okra plant have benefits in the body. Also, okra conceives anthocyanin as a flavonoid compound responsible for the blue, purple, and red in leaves and fruits (Irshad et al., 2018). The okra pods have flavonoid compounds that act as antioxidants (Irshad et al., 2018; Anjani et al., 2018). It is a scavenger of free radicals (Xia et al., 2015) by donating their electrons to the oxidants (Husen et al., 2019). Several studies have shown a reduction in oxidative stress after treatment with antioxidants (Sherif \& AlGayyar, 2013). Green okra pods contain polysaccharides that act as immunomodulators against Staphylococcus aureus infection (Wahyuningsih et al., 2017).

The flavonoids okra can induce to the nuclear factor-E2-related factor 2-antioxidant response element (Nrf2-ARE). This activity triggers the genes to transcribe antioxidant enzymes such as superoxide dismutase (SOD) and catalase (CAT) (Muriel \& Gordillo, 2016). SOD can band superoxide and form non-toxic hydrogen peroxide (Luo et al., 2018). Based on the results of research conducted by Wahyuningsih et al. (2020), that giving various doses of methanol extract of okra, proven to have nephroprotective activity by reducing levels of BUN and Cre, including kidney healing and reduced levels of cell damage with lowered necrosis and apoptosis due induction-lead.

However, evaluating the effect of red okra pods ethanol extract (ROE) on mice exposed to sodium nitrite has never been done before. This study aimed to reveal the potential of ROE to improve the kidney against oxidative stress in mice exposed to sodium nitrite as indicated by BUN, Cre, MDA and SOD levels in serum, percentage of normal cells, necrotic cells, and swelling cells from PCT in histological structure. The results of this study can be used for information about the benefits of okra pods as a food ingredient to reduce kidney damage due to synthetic preservative sodium nitrite.

\section{METHOD}

This research was conducted in three laboratories in the Department of Biology, Faculty of Science and Technology, Airlangga University. Mice acclimatization and rearing were undertaken at Animal Laboratory. Kidney's histological observation was done in Histology Laboratory and measurement of BUN and creatinine level were carried out at Molecular Genetics Laboratory.

\section{Materials}

Ethanol extract of red okra was made from fresh red okra pods obtained from a traditional Surabaya market. Biotech ${ }^{\circledR}$ MDA-586 spectrophotometric assay kit and SOD typed assay kit (E-BC-K022) were used in this study. BUN and creatine levels were measured using kits from Diagnostic Systems GmbH with their respective catalog numbers, Cat. No. 1 3101991027 for BUN and Cat. No. 117119910021 for creatinine. Sodium nitrite powder was purchased from Merck, Germany. The other chemicals such as ethanol, neutral buffer formalin, xylol, paraffin, entellan, acid ethanol, and hematoxylin-eosin were also used in this study.

\section{Plant material and preparation}

The fresh red okra pods were cut. It dried in the shade for seven days. These $296 \mathrm{~g}$ of dried pods were powdered and macerated in $96 \%$ ethanol for $72 \mathrm{~h}$. The concentrates were collected every $24 \mathrm{~h}$ for three times. The solvent removed at $60^{\circ} \mathrm{C}$ using a rotary evaporator. The evaporated extract $(60 \mathrm{~mL})$ was freeze-dried. This method yielded an ROE of $60.4 \mathrm{~g}$.

\section{Animal and experimental design}

The research have been approved by the Animal Care, and Use Committee, Faculty of Veterinary Medicine, Airlangga University with No. 2.KE.138.06.2019. The adult male mice (Mus musculus) BALB/c strain aged 8-10 weeks were used to research came from Pusvetma Surabaya. The 36 mice were acclimatized for one week and divided into six groups. This is control (K), negative control (K-), and four groups of ROE treatment. The okra dose variations were $25 \mathrm{mg} / \mathrm{kg} \mathrm{BW}(\mathrm{P} 1), 50 \mathrm{mg} / \mathrm{kg} \mathrm{BW}$ 
(P2), $75 \mathrm{mg} / \mathrm{kg} \mathrm{BW}(\mathrm{P} 3)$, and $100 \mathrm{mg} / \mathrm{kg} \mathrm{BW}(\mathrm{P} 4)$. Induction with sodium nitrite was carried out once every day for 23 days at a $50 \mathrm{mg} / \mathrm{kg}$ BW dose, followed by $0.2 \mathrm{~mL}$ ROE $30 \mathrm{~min}$ after induction of $\mathrm{NaNO}_{2}$. Sodium nitrite and ROE were administered orally.

\section{Serum isolation}

Blood serum was collected on the $24^{\text {th }}$ day. Serum isolation was started with collecting $1 \mathrm{~mL}$ of blood from the mice from the heart. The blood was collected in a microtube and placed on its side for 2 hours at room temperature. Centrifugation was performed at a speed of $3000 \mathrm{rpm}$ at $4^{\circ} \mathrm{C}$ for $10 \mathrm{~min}$. The serum (supernatant) was then transferred to a new microtube and stored for further analysis.

\section{Quantification of SOD and MDA levels in serum}

The SOD-Typed Assay kit (E. BC-K022-5) used to measure SOD activity. $20 \mu \mathrm{L}$ serum inserted in the tube and added with $\mathrm{R} 1$ of $100 \mu \mathrm{L}$ and distilled water of $20 \mu \mathrm{L}, \mathrm{R} 2$ of $10 \mu \mathrm{L}, \mathrm{R} 3$ of $10 \mu \mathrm{L}$, and $\mathrm{R} 4$ of $10 \mu \mathrm{L}$. The mixe was vortexed and incubated for $40 \mathrm{~min}$ at $37^{\circ} \mathrm{C}$, and the chromogenic agent of $200 \mu \mathrm{L}$ was added. The absorbances were read at wavelength of $550 \mathrm{~nm}$ using a spectrophotometer (Thermo Scientific ${ }^{\mathrm{TM}}$ Multiskan ${ }^{\mathrm{TM}} \mathrm{GO}$ ), and the activity of SOD was calculated based on the manufacturer's instruction.

The $80 \mu \mathrm{L}$ of serum was blend with Probucol of 4 $\mu \mathrm{L}, \mathrm{R} 1$ solution of $256 \mu \mathrm{L}$, and $\mathrm{R} 2$ solution of 150 $\mu \mathrm{L}$. The mixture was incubated $\left(60 \mathrm{~min}, 45^{\circ} \mathrm{C}\right)$ and then centrifuged $(10000 \mathrm{~g}, 10 \mathrm{~min})$. The supernatant was moved to a 96-well microplate. Furthermore, the OD value of MDA was read with microplate UV-Vis spectrophotometer at wavelength $586 \mathrm{~nm}$ and 540 $\mathrm{nm}$.

\section{Histological evaluation of kidney}

The kidney organ was cut into 2 . Then, it fixed in neutral buffered formalin $(48 \mathrm{~h})$. The organ were processed manually using graded ethanol $(70 \%, 80 \%$, $90 \%$, and $100 \%$ ) and then embedded in a paraffin block. It sectioned to tissue a thickness of $5 \mu \mathrm{m}$ with a rotary microtome. The tissue was stained using hematoxylin-eosin. It were examined for histological changes, such as normal, necrotic, and swelling cells using a light microscope at magnification $40 x$.

\section{Quantification of BUN and creatinine level}

BUN and creatinine measurements were carried out according to the Diasys kit's procedure (Diagnostic system). Standard solution, $10 \mu \mathrm{L}$ serum for BUN levels, and $50 \mu \mathrm{L}$ serum for creatinine levels were mixed with $1000 \mu \mathrm{L}$ buffer $\mathrm{R} 1$. Then the absorbance was measured at $340 \mathrm{~nm}$ and $492 \mathrm{~nm}$ for BUN and creatinine, respectively.

\section{Data analysis}

All data produced experiment were analyzed using one-way analysis of variance (One Way ANOVA). Data with significant difference was proceed with the Duncan test to determine the difference between treatment groups with $\alpha=0.05$.

\section{RESULTS AND DISCUSSION}

\section{Effect of ROE on SOD and MDA levels in serum}

SOD and MDA levels can be seen in Table 1. The SOD activity in the $\mathrm{P} 1, \mathrm{P} 2, \mathrm{P} 3$, and $\mathrm{P} 4$ groups significantly went up compared with the negative control (K-). SOD levels were lowest in the treatment with only sodium nitrite. Different results were shown on MDA levels. The MDA test revealed that the MDA level lowest was found in the normal control $(\mathrm{K}+)$, whereas $\mathrm{K}$ - had the highest. ROE at a level of $100 \mathrm{mg} / \mathrm{kg}$ BW reduced the MDA levels compared to K-, but it has not been able to return it to normal levels.

Table 1. Effect of ROE on SOD and MDA level in serum of sodium nitrite exposed mice

\begin{tabular}{lllllll}
\hline Indicator & $\mathrm{KN}$ & $\mathrm{K}-$ & $\mathrm{P} 1$ & $\mathrm{P} 2$ & $\mathrm{P} 3$ & $\mathrm{P} 4$ \\
\hline SOD $(\mathrm{U} / \mathrm{mL})$ & $0.55 \pm 0.04 \mathrm{~d}$ & $0.35 \pm 0.02 \mathrm{a}$ & $0.4 \pm 0.02 \mathrm{~b}$ & $0.45 \pm 0.01 \mathrm{c}$ & $0.48 \pm 0.03 \mathrm{c}$ & $0.50 \pm 0.03 \mathrm{c}$ \\
MDA $(\mu \mathrm{M})$ & $28.6 \pm 1.07 \mathrm{a}$ & $90.8 \pm 1.87 \mathrm{c}$ & $88.3 \pm 5.60 \mathrm{c}$ & $89.6 \pm 3.73 \mathrm{c}$ & $89.0 \pm 2.59 \mathrm{c}$ & $51.7 \pm 2.6 \mathrm{~b}$ \\
\hline
\end{tabular}

Different letter in each section shows a significant difference $(\alpha=0.05)$. KN: Normal control, K-: Negative control (sodium nitrite of $50 \mathrm{mg} / \mathrm{kg} \mathrm{BW}$ ), P1: sodium nitrite and ROE of $25 \mathrm{mg} / \mathrm{kg} \mathrm{BW}, \mathrm{P} 2$ : sodium nitrite and ROE of $50 \mathrm{mg} / \mathrm{kg} \mathrm{BW}, \mathrm{P} 3$ : sodium nitrite and ROE of $75 \mathrm{mg} / \mathrm{kg} \mathrm{BW}$, and P4: sodium nitrite and ROE of $100 \mathrm{mg} / \mathrm{kg} \mathrm{BW}$.

The nitrite group in $\mathrm{NaNO}_{2}$, when induced into the body, will enter the stomach and then pass through the small intestine, where it will be absorbed into the blood. Nitrite in blood and tissue is reduced to NO, a product of ROS and RNS. Nitric oxide, which is formed when it binds to one of the ROS products, namely superoxide, will produce peroxynitrite. The peroxynitrite compound will form a reaction with polyunsaturated fatty acid (PUFA), accelerating lipid peroxidation (Liaudet et al., 2013). The increase in lipid peroxidation can lead to increased oxidative stress (Özen et al., 2014). Vitamin C, carotenoids, 
phenolic, and flavonoid compounds are used as antioxidants that can capture and scavenge free radicals, inhibit the synthesis of the radicals by chelating metal ions and neutralize them from causing molecular oxidation in the cells (Kumar \& Pandey, 2013; Petropoulos et al., 2017). Research by Susatyo et al. (2018) reports that endogenous antioxidants as protective agents in the body can reduce because free radicals increase. Whilst, phenolic and carotenoid compounds within microalgae Chlorella vulgaris can be utilized as exogenous antioxidants. In line with the study of Susatyo et al. (2018), in this research, the antioxidants contained in red okra extract can stabilize free radicals. this is indicated by increasing levels of SOD while MDA levels drop. Vitamin C depressed the lipid peroxidation level to normal.

In this study, it was proven that ROE could improve SOD, even though not restore SOD to normal yet. Flavonoids as antioxidants have three components utilized to anticipate the damage caused by free radicals. The primary mechanism is clampdown the generation of RNS by hindering the proteins included in RNS syntheses such as microsomal monooxygenase, glutathione stransferase, mitochondrial succinoxidase, and NADH oxidase or by chelating the trace components included within the arrangement of free radicals. The second and third components are direct scavenging of RNS and upregulation or protection of the antioxidant defense framework (Galleano et al., 2010; Kumar \& Pandey, 2013).

\section{Effect of ROE on kidney histology}

Based on the results obtained in Figure 1, the treatment of sodium nitrite (K-, 69.2 $\pm 2.8 \%$ ) increases necrosis and decreases normal cells in kidney cells

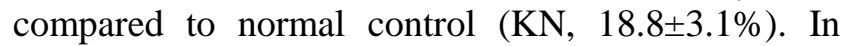
contrast, the mean PCT cells necrosis in P1, P2, P3, and $\mathrm{P} 4$ were $61.5 \pm 3.3 \%, 60.6 \pm 1.1 \%, 60.8 \pm 2.1 \%$, and $47.3 \pm 3.2 \%$ respectively. Sodium nitrite is detrimental at high concentrations due to its ability to form free radicals. Based on Muriel \& Gordillo (2016), the effect of free radicals includes cellular membrane damage through lipid peroxidation, destruction of the cytosolic enzymes and membrane proteins through protein oxidation, and mutation in the mitochondrial DNA. The mutation causes cellular damage.

This study reveals that sodium nitrite does not affect the number of cells swelling in PCT. The mean PCT cells swelling in KN, K-, P1, P2, P3, and P4 were $1.9 \pm 0.23 \%, 1.5 \pm 0.19 \%, 0.4 \pm 0.02 \%, 0,3 \pm 0.15 \%$, $0.4 \pm 0.03 \%$, and $2.5 \pm 0.35 \%$, respectively. It can occur because the swelling is a reversible process, meaning that it can be fixed if the exposure is removed immediately. However, if the exposure occurs continuously, the cell swelling becomes acute. The cells failed to improve electrolyte balance and loss of cell volume control. The reversible cell injury can turn into a necrosis stage (Miller \& James, 2017). With the high percentage value of necrotic cells in PCT, it can be seen that there has been structural damage to the kidneys.

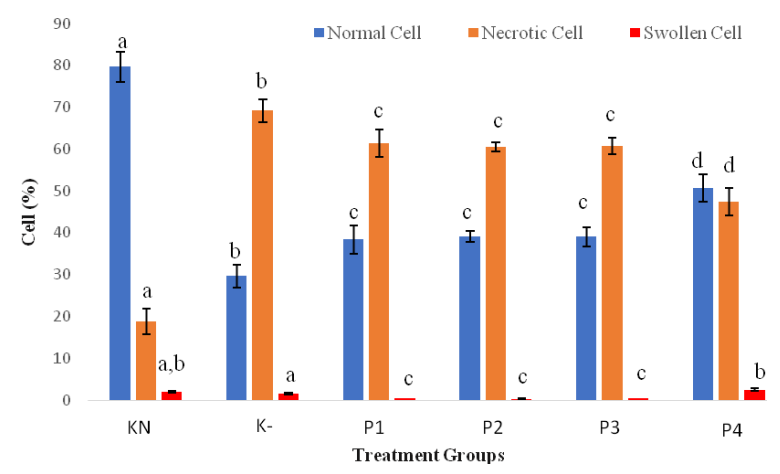

Figure 1. Percentage of normal, necrotic, and swollen cells in PCT of sodium nitrite exposed mice. Different letters in each section show a significant difference $(\alpha=0.05)$. KN: Normal control, K-: Negative control (sodium nitrite of $50 \mathrm{mg} / \mathrm{kg} \mathrm{BW}$ ), $\mathrm{P} 1$ : sodium nitrite and $\mathrm{ROE}$ of $25 \mathrm{mg} / \mathrm{kg} \mathrm{BW}, \mathrm{P} 2$ : sodium nitrite and ROE of $50 \mathrm{mg} / \mathrm{kg} \mathrm{BW}$, P3: sodium nitrite and ROE of $75 \mathrm{mg} / \mathrm{kg} \mathrm{BW}$, and P4: sodium nitrite and ROE of $100 \mathrm{mg} / \mathrm{kg} \mathrm{BW}$.

The results of histology observations of the PCT (Figures 1 and 2), it can be seen that in the administration of ROE (P1, P2, P3, and P4 groups), there was an increase in the percentage of normal cells and a decrease in swollen and necrosis cells. The mean normal PCT cells in KN, K-, P1, P2, P3, and P4 were $79.6 \pm 3.6 \%, 29.7 \pm 2.8 \%, 38.8 \pm 3.3 \%, 39.2 \pm 1.3 \%$, $39.0 \pm 2.3 \%$, and $50.8 .5 \pm 3.3 \%$. Although there were no significant differences among $\mathrm{P} 1, \mathrm{P} 2$, and $\mathrm{P} 3$, they differed significantly from negative controls (K-). It proves that administering ROE doses of $25,50,75$, and $100 \mathrm{mg} / \mathrm{kg} \mathrm{BW}$ improved kidney histology due to exposure to sodium nitrite. The $\mathrm{P} 4$ treatment group with a dose of $100 \mathrm{mg} / \mathrm{kg} \mathrm{BW}$ of ROE was the most effective in cell repair, as indicated by a significant increase in the percentage of normal cells and decreased the percentage of necrotic cells in all remaining treatment groups.

The ROE contains flavonoid compounds i.e. catechin, epicatechin, procyanidin B1 and B2, quercetin, and rutin (Tongjaroenbuangam et al., 2011). These compounds are used as antioxidants that can capture and scavenge free radicals, inhibit the radicals' synthesis by chelating metal ions and neutralize them from causing molecular oxidation in the cells (Kumar \& Pandey, 2013; Petropoulos et al., 2017). Similar results exist in the Fitmawati et al. 
(2019) study, the damage that occurs in the kidneys only occurs in small amounts and is still in the normal range of less than $25 \%$, this is a result of the immunomodulators and antioxidants contained in obat pahit.

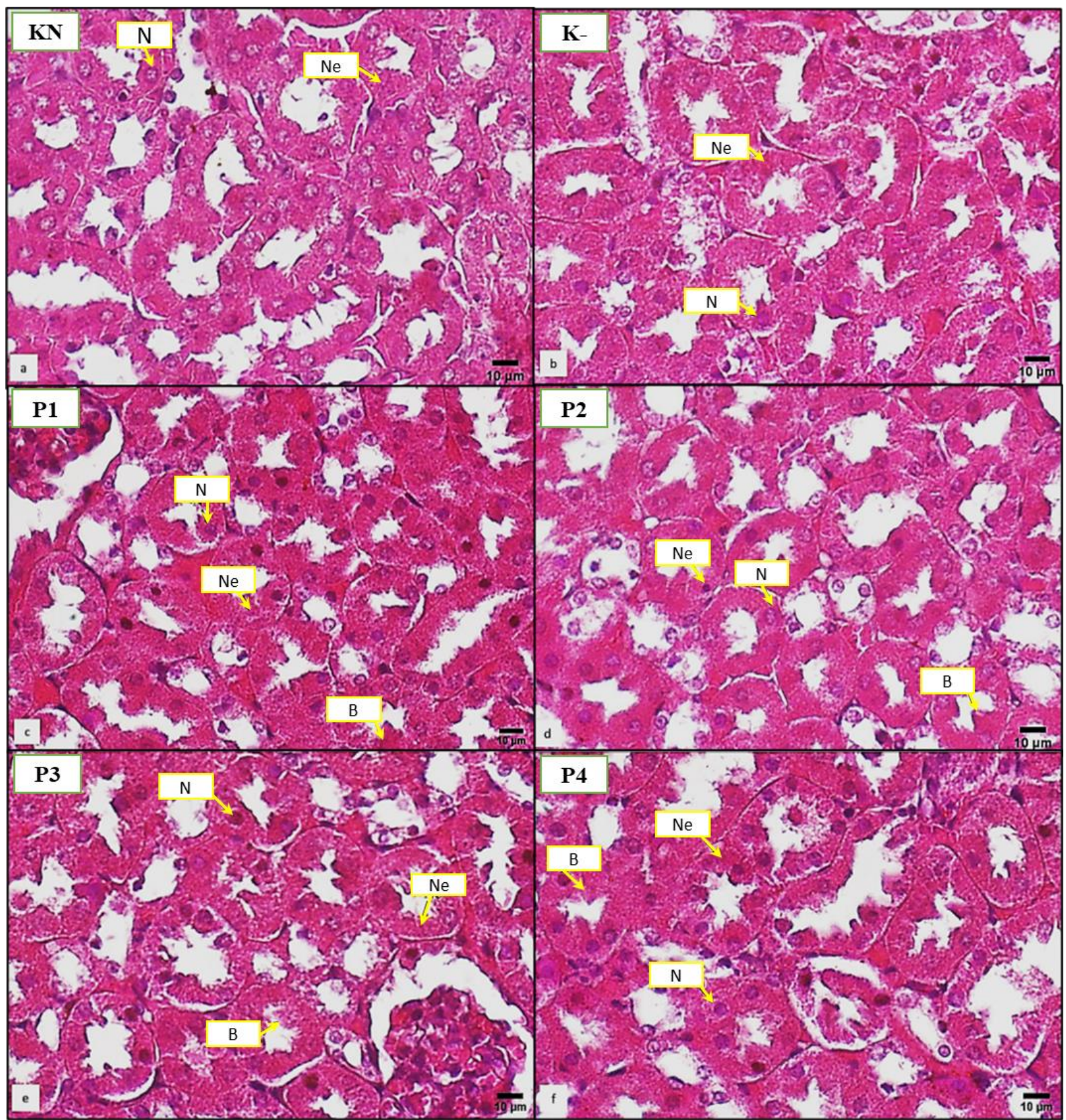

Figure 2. Kidney histology of sodium nitrite exposed mice. a: control, b: negative control, c-f: treatment groups. N: normal cell, B: bulging/swollen cell, Ne: necrotic cell. KN: Normal control, K-: Negative control (sodium nitrite of $50 \mathrm{mg} / \mathrm{kg} \mathrm{BW}$ ), P1: sodium nitrite and ROE of $25 \mathrm{mg} / \mathrm{kg} \mathrm{BW}, \mathrm{P} 2$ : sodium nitrite and ROE of $50 \mathrm{mg} / \mathrm{kg} \mathrm{BW}$, P3: sodium nitrite and ROE of $75 \mathrm{mg} / \mathrm{kg} \mathrm{BW}$, and P4: sodium nitrite and ROE of $100 \mathrm{mg} / \mathrm{kg}$ BW.

Sodium nitrite will be broken down inside the human body into NO compounds, which are free radicals. These free radicals will cause oxidative stress that can cause tissue damage, including the kidneys' tissue. One of the antidotes for oxidative stress is antioxidants, which have a scavenging mechanism for free radical molecules. The plant of red okra embody various antioxidant compounds such

as quercetin, phenolic acids, and flavonoids (Flora et al., 2012). Exogenous antioxidant compounds from foods such as red okra can help reduce and neutralize oxidative stress, helping repair damaged tissue.

\section{Effect of ROE on BUN and creatinine levels in serum}

A decrease in the glomerular filtration rate and the absorption ability of the PCT can be caused for 
damage to the renal structural. Decreased glomerular filtration rate makes BUN and creatinine levels, which should be filtered by the glomerulus, climb their level in the blood serum. Creatinine will also be actively secreted through the PCT. If the tubular absorption capacity is decreased due to structural damage, the creatinine level in the blood will also increase (Gounden et al., 2020). BUN and creatinine levels in the serum of mice exposed to sodium nitrite also showed the highest values in the negative control group (K-). In Figure 3, the mean of BUN level in $\mathrm{KN}, \mathrm{K}-, \mathrm{P} 1, \mathrm{P} 2, \mathrm{P} 3$, and $\mathrm{P} 4$ were $24.4 \pm 3.2,49.7 \pm 4.4$, $32.7 \pm 2.8,30.9 \pm 5.7,35.7 \pm 2.8$, and $28.5 \pm 4.9 \mathrm{mg} / \mathrm{dL}$, respectively. Whilst in Figure 4, the mean of creatinine in $\mathrm{KN}, \mathrm{K}-, \mathrm{P} 1, \mathrm{P} 2, \mathrm{P} 3$, and $\mathrm{P} 4$ were $0.19 \pm 0.04, \quad 0.46 \pm 0.07, \quad 0.41 \pm 0.08, \quad 0.37 \pm 0.09$, $0.43 \pm 0.08$, and $0.22 \pm 0.08 \mathrm{mg} / \mathrm{dL}$, respectively.

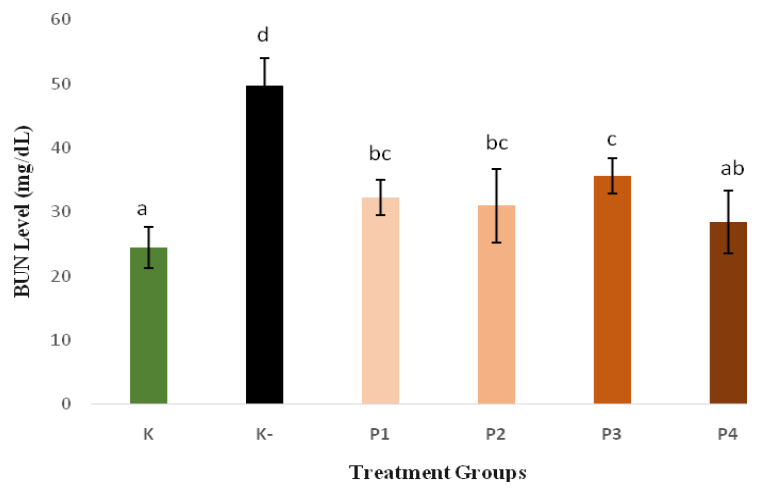

Figure 3. BUN level in blood serum of sodium nitrite exposed mice. Different letter in each section shows a significant difference $(\alpha=0.05)$. KN: Normal control, K-: Negative control (sodium nitrite of $50 \mathrm{mg} / \mathrm{kg}$ BW), P1: sodium nitrite and ROE of $25 \mathrm{mg} / \mathrm{kg} \mathrm{BW}$, P2: sodium nitrite and ROE of $50 \mathrm{mg} / \mathrm{kg} \mathrm{BW}, \mathrm{P} 3$ : sodium nitrite and ROE of $75 \mathrm{mg} / \mathrm{kg} \mathrm{BW}$, and P4: sodium nitrite and ROE of $100 \mathrm{mg} / \mathrm{kg} \mathrm{BW}$.

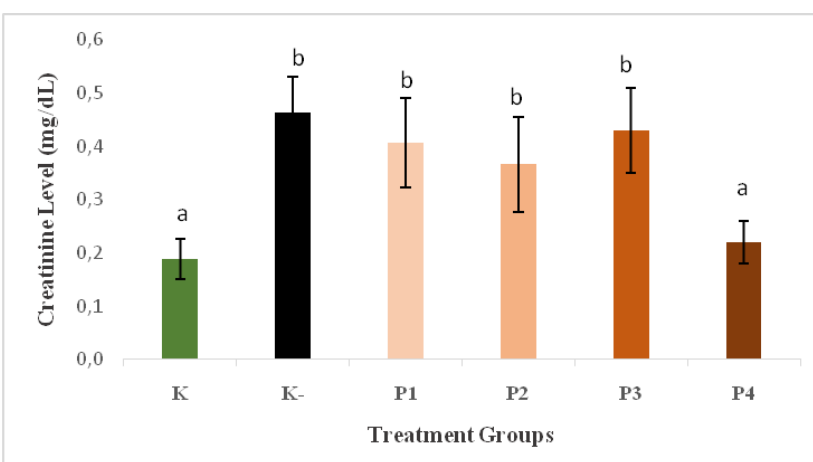

Figure 4. Creatinine level in blood serum of sodium nitrite exposed mice. Different letter in each section shows a significant difference $(\alpha=0.05)$. KN: Normal control, K-: Negative control (sodium nitrite of 50 $\mathrm{mg} / \mathrm{kg} \mathrm{BW}$ ), P1: sodium nitrite and ROE of $25 \mathrm{mg} / \mathrm{kg}$ BW, P2: sodium nitrite and ROE of $50 \mathrm{mg} / \mathrm{kg} \mathrm{BW}$, P3: sodium nitrite and ROE of $75 \mathrm{mg} / \mathrm{kg} \mathrm{BW}$, and P4: sodium nitrite and ROE of $100 \mathrm{mg} / \mathrm{kg} \mathrm{BW}$.
.The rise in BUN is frequently related with renal failure. At the same time, creatinine is commonly utilized as a measuring the work of the kidneys and the primary step in controlling the glomerular filtration rate (Salazar, 2014). The increment in creatinine showed in mice treated with sodium nitrite is related to the glomerular filtration rate diminishment related with oxygen free radical arrangement. BUN and creatinine values were rised in mice treated with sodium nitrite.

In compliance with the results of renal histology, the P4 treatment group had the most significant decrease in BUN levels and creatinine of the blood serum. The ROE at a dose of $100 \mathrm{mg} / \mathrm{kg} \mathrm{BW} \mathrm{(P4)}$ significantly decreased BUN and creatinine levels in serum compared with the negative control group. Concurrently, the other treatment groups moreover showed diminished BUN and creatinine levels compared to the negative control group, in spite of the fact that the results were not significant. Improvement of kidney tissue that occurs due to red okra ethanol extract will improve the renal performance, so that BUN and creatinine levels decrease. Both BUN and creatinine significantly decreased in serum levels of ROE-treated rats due to sodium nitrite induction Both BUN and creatinine significantly decreased in serum levels of ROEtreated rats due to sodium nitrite induction. These could be due to reduced renal damage by the ROE. These results suggest that antioxidant compound in red okra could be utilized to restore kidney damage due to its antioxidant activity.

\section{CONCLUSION}

The red okra ethanol of extract administrated can improve SOD level, mitigate MDA, restore PCT tissue damage, and reduce BUN and creatinine levels in blood serum of mice exposed to sodium nitrite with the most effective dose of $100 \mathrm{mg} / \mathrm{kg} \mathrm{BW}$. The red okra ethanol extract (ROE) as an antioxidant can repair kidney damage in mice (Mus musculus), which is exposed to oxidants from food preservatives in the form of $\mathrm{NaNO}_{2}$.

\section{ACKNOWLEDGMENTS}

This work was funded by Penelitian Dasar Unggulan Perguruan Tinggi, Universitas Airlangga, Indonesia (grant number: 992/UN3.14/PT/2020).

\section{REFERENCES}

Anjani, P. P., Damayanthi, E., Rimbawan, R., \& Handharyani, E. (2018). Antidiabetic potential of purple okra (Abelmoschus esculentus L.) extract in 
streptozotocin-induced diabetic rats. IOP Conference Series: Earth and Environmental Science, 196(2018), 012038.

Ansari, F. A., Ali, S. N., Arif, H., Khan, A. A., \& Mahmood, R. (2017). Acute-oral dose of sodium nitrite induces redox imbalance, DNA damage, metabolic, and histological changes in rat intestine. PLoS One, 12(4), e0175196.

Baek, J. H., Zhang, X., Williams, M. C., Hicks, W., Buehler, P. W., \& D'Agnillo, F. (2015). Sodium nitrite potentiates renal oxidative stress and injury in hemoglobin exposed guinea pigs. Toxicology, 333, 89-99.

Bijanti., M., Gundul A. Y., Retno S. W., \& Budi U. (2010). Patologi klinik veteriner Edisi Pertama. Surabaya: Pusat Penerbitan dan Percetakan Unair.

Fitmawati, Saputra, A., Titrawani, Juliantari, E., \& Dewi, A. P. K. (2019). Histological study of white rats (Rattus norvegicus) kidney following the consumption of obat pahit from Riau archipelago. Biosaintifika, 11(2), 211-217.

Flora, G., Gupta, D., \& Tiwari, A. (2012). Toxicity of lead: a review with recent updates. Interdisciplinary Toxicology, 5(2), 47-58.

Galleano, M., Verstraeten, S. V., Oteiza, P. I., \& Fraga, C. G. (2010). Antioxidant actions of flavonoids: Thermodynamic and kinetic analysis. Archives of Biochemistry and Biophysics, 501(1), 23-30.

Gounden, V., Bhatt, H., \& Jialal, I. (2020). Renal Function Tests. Retrieved from https://www.ncbi.nlm.nih.gov/books/NBK507821/

Guzel, S., Sahinogullari, Z. U., Canacankatan, N., Antmen, S. E., Kibar, D., \& Coskun Yilmaz, B. (2019). Potential renoprotective effects of silymarin against vancomycin-induced nephrotoxicity in rats. Drug and Chemical Toxicology, 43(6), 630-636.

Husen S. A., Wahyuningsih, S. P. A., Ansori, A. N. M., Hayaza S., Susilo, R. J. K., Darmanto, W., \& Winarni, D (2019). The effect of okra (Abelmoschus esculentus Moench) pods extract on malondialdehyde and cholesterol level in STZinduced diabetic mice. Ecology, Environment, and Conservation, 25(4), 3703-3708.

Irshad, M., Debnath, B., Mitra, S., Arafat, Y., Li, M., Sun, Y., \& Qiu, D. (2018). Accumulation of anthocyanin in callus cultures of red-pod okra [Abelmoschus esculentus (L.) Hongjiao] in response to light and nitrogen levels. Plant Cell, Tissue and Organ Culture, 134(1), 29-39.

Kumar, S., \& Pandey, A. K. (2013). Chemistry and biological activities of flavonoids: an overview. The Scientific World Journal. Article ID 162750.
Kumar, V., Abbas, A. K. \& Aster, J. C. (2015). Robbins \& cotran pathologic basis of disease. 9th Edition, Elsevier, Philadelphia.

Lee, S., Lee, H., Kim, S., Lee, J., Ha, J., Choi, Y., Oh, H., Choi K., \& Yoon, Y. (2018). Microbiological safety of processed meat products formulated with low nitrite concentration-a review AsianAustralasian Journal of Animal Sciences, 31(8), 1073-1077.

Liaudet, L., Rosenblatt-Velin, N., \& Pacher, P. (2013). Role of peroxynitrite in the cardiovascular dysfunction of septic shock. Current Vascular Pharmacology, 11(2), 196-207.

Luo, Y., Hong-Xin, C., An, J., Shan-Shan, J. \& Ke, Y. (2018) The protective effect of the total flavonoids of Abelmoschus esculentus L. flowers on transient cerebral ischemia-reperfusion injury is due to activation of the Nrf2-ARE pathway. Oxidative Medicine and Cellular Longevity, Article ID 8987173.

Miller, M. A. \& James, F. Z. (2017). Mechanisms and morphology of cellular injury, adaptation, and death. Pathologic Basis of Veterinary Disease, 243, e19.

Muriel, P., \& Gordillo, K. R. (2016). Role of oxidative stress in liver health and disease. Oxidative Medicine and Cellular Longevity, Article ID 9037051.

Nur, H. H., \& Suryani, D. (2011). Analisis kandungan nitrit dalam sosis pada distributor sosis di kota Yogyakarta tahun 2011. Jurnal Kesehatan Masyarakat (Journal of Public Health), 6(1), 174.

Özen, H., Kamber, U., Karaman, M., Gül, S., Atakişi, E., Özcan, K., \& Atakişi, O. (2014). Histopathologic, biochemical, and genotoxic investigations on chronic sodium nitrite toxicity in mice. Experimental and Toxicologic Pathology, 66(8), 367-375.

Petropoulos S., Di Gioia, F., \& Ntatsi, G. (2017). Vegetable organosulfur compounds and their health-promoting effects. Current Pharmaceutical Design, 23, 2850-2875.

Post, A., Tsikas, D., \& Bakke, S. J. L. (2019). Creatine is a conditionally essential nutrient in chronic kidney disease: a hypothesis and narrative literature review. Nutrients 11(5), 1044.

Salazar, J. H. (2014). Overview of urea and creatinine. Winter, 45(1), e19-e20.

Seki, M, Nakayama, M., Sakoh, T., Yoshitomi, R., Fukui, A., Katafuchi, E., Tsuda, S., Nakano, T., Tsuruya, K., \& Kitazono, T. (2019). Blood urea nitrogen is independently associated with renal outcomes in Japanese patients with stage 3-5 chronic kidney disease: a prospective 
observational study. BMC Nephrology, 20(115), $1-10$.

Sherif, I. O., \& Al-Gayyar, M. M. (2013). Antioxidant, anti-inflammatory, and hepatoprotective effects of silymarin on hepatic dysfunction induced by sodium nitrite. European Cytokine Network, 24(3), 114-1.

Susatyo, P., Rifanda, A. A., Simanjuntak, S. B. I., \& Chasanah, T. (2018). Antioxidant effect of Chlorella vulgaris on Wistar rat kidney induced by $\mathrm{CCl}_{4}$ : a histopathological review. Biosaintifika, 10(1), 169-175.

Tongjaroenbuangam, W., Ruksee, N., Chantiratikul, P., Pakdeenarong, N., Kongbuntad, W., \& Govitrapong, P. (2011). Neuroprotective effects of quercetin, rutin, and okra (Abelmoschus esculentus Linn.) in dexamethasone-treated mice. Neurochemistry International, 59(5), 677-685.

Wahyuningsih, S. P. A., Pramudya, M., Putri, I. P., Savira, N. I. I., Winarni, D., Suhargo, L.,
Darmanto, W. (2017). Okra polysaccharides improve spleen weight and B-lymphocytes proliferation in mice infected by Staphylococcus aureus. Biosaintifika, 9(3), 460-465.

Wahyuningsih, S. P. A., Savira, N. I. I., Anggraini, D. W., Winarni, D., Suhargo, L., Kusuma, B. W. A., Nindyasari, F., Setianingsih, N., \& Mwendolwa, A. A. (2020). Antioxidant and nephroprotective effects of okra pods extract (Abelmoschus esculentus L.) against lead acetate-induced toxicity in mice. Scientifica, Article ID 4237205.

Wójciak, K. M., Stasiak, D. M., \& Kęska, P. (2019). The influence of different levels of sodium nitrite on the safety, oxidative stability, and color of minced roasted beef. Sustainability, 11(14), 3795.

Xia, F., Zhong Y., Li, M., Chang, Q, Liao, Y., Liu, X., \& Pan, R. (2015). Antioxidant and anti-fatigue constituents of okra. Nutrients, 7(10), 8846-8858. 